\title{
The Social Role of Art and the Artist in the Ballads of Günter Grass and Wolf Biermann
}

\author{
Dr. Jelena Knežević
}

University of Montenegro

Email: jelenak@ac.me

\section{Doi:10.5901/mjss.2014.v5n13p257}

\begin{abstract}
The aim of this paper is to show how the German artistic ballad reflects the question of the social role of art and the artist in the second half of the 20th century, when - parallel with the affirmation of the concept of socially engaged and conscious art - the question of the status of an intellectual in society becomes very important. Within this study of German ballad, this literary and musical genre is understood as a short discursive form that deals with existential questions and stoned truths and values by means of apparently naive and simple presented events, offering in that way an opportunity for critical reflection in the act of reception. Two representative ballads are interpreted within this paper: Adorno's tongue (Adornos Zunge, 1965) from Günter Grass and Ballad to the Poet François Villon (Ballade auf den Dichter François Villon, 1968) from Wolf Biermann. The immanent text interpretation of the two selected ballads shows the way in which literature, as an aesthetic response to reality, can offer the relevant critical perception of society, considering the historical moment of origin of the text as well as the philosophical and existential views of the author.
\end{abstract}

Keywords: German artistic ballad, Günter Grass, Wolf Biermann, social role, artist.

\section{Introduction}

German ballad, the literary and musical genre that returned to popularity at the end of the $20^{\text {th }}$ century, is today understood as a short discursive form that deals with existential questions and stoned, "eternal" truths and values by means of apparently naive and simple presented events, offering in that way an opportunity for critical reflection in the act of reception. Today's understanding of the ballad as an "epic-fictional literary genre" follows the previous theoretical and historical consideration of ballad that received a fresh impetus at the end of the $20^{\text {th }}$ century (Laufhütte, 1992). The discussion about the range and expressive possibilities of the ballad ran parallel with the development of ballad writing. ${ }^{1}$ In accordance with the model of Hartmut Laufhütte from 1991, explained and amended by Srdan Bogosavljević, within this research, ballad is understood as a narrative fiction, which differs from other epic genres not by its topics, but rather by the fact that the narrated occurrence - "the unusual event or conflict" - is structured teleologically (Bogosavljević, 2006). The ballad aims to tell the story in the way that enables the "critical reflection of the narrated occurrence in the act of reception" (Laufhütte, 1991).

Two different narrative styles developed within the two parallel traditions of the ballad: serious, direct narration on the one side and an ironic game of wit on the other. These two traditions were radically separated in the $19^{\text {th }}$ century due to their perceived artistic value. Hence, we no longer read ballad as a mix of literary genres, as previously defined (from Goethe to Kayser), but rather as a mix of the two aforementioned narrative styles that can be easily identified in the works of Hölty, Goethe, Schiller, Heine and Meyer in $19^{\text {th }}$ century, as well as in those of Brecht, Grass and Ulla Hahn in the $20^{\text {th }}$ century (Laufhütte, 2009). The sustainable source of the modernity of the genre can be found within that mix. That can be proven in a relevant short historical overview of ballad as a genre that developed choosing a variety of different motives and topics while using apparently naive narration. This type of narration distances an object from the narrative instance, enabling direct, although not simplified, insight into the basic human, natural and destiny relations, as well as in the social and historical questions, opening in that way space for their reflection. Making an issue out of the status of the reality or making a problem out of the chosen point of view, as well as unexpectedly changing the narrative instances and shifting the presented events into the fantastic or unrealistic sphere are typical literary means used in the ballad to enable individual reflection, so that the reader can come to his or her own conclusions, without docility and using his or her own cognitive and creative potential.

\footnotetext{
${ }^{1}$ More about the theoretical consideration of the ballad in 19th and 20th century in: Müller-Seidel, 1980. Literature overview and the brief history of the genre in: Knežević, 2013.
} 
The new theoretical perspective in the $20^{\text {th }}$ century made it possible to connect the old and new tradition of the ballad and with it the paradigm shift in the theory of this genre. At the same time, the different new perspectives in the humanities that the ballad of $20^{\text {th }}$ century chooses for its reflection of existential and social questions, made possible the new understanding of old, always current topics or rather their reconsideration and reevaluation. One of them is the issue of how art is understood.

During the historical development of the genre, starting from the second half of the $18^{\text {th }}$ century up until modern day, ballad tends to make the art and artist the subject of discussion. In the more than 200-year long history of the genre, the ballad reflects the questions of literature, its origins and nature, its effectiveness and power, as well as the social role of the poet. From Löwen's Zuverlässige Geschichte (True Story), through Goethe's Sänger (Singer) and Schiller's Ibykus to Heine's Firdusi and Laotse from Brecht, the ballad proves itself as a self-confident literary genre, which dares to sing about itself. The mentioned topics are questioned in both serious and satirical-comic tradition of the ballad and alternately answered from two different points of view - affirmative and critical. Not only Goethe and Schiller believed in the power of art to transform society through the individual education gained within an aesthetic activity. Their faith had to do with their belief in the transcendental origin of the poetry, which they shared with the Romantics. Although skeptical about the social ranking of an artist and with no faith in transcendental, the critical tradition of the ballad, as old as an affirmative one, also asks art to be an instrument - a sharp instrument of criticism that reveals social and individual weaknesses through narration.

The ballad of the $20^{\text {th }}$ century understands the arts in the way its age does: from the complete social alienation of an artist in Neo-romanticism, through the call for the political involvement and truth that needs to be said to the postmodern demand for critical revision of any doctrine. With the affirmation of the concept of political involved and socially conscious art, the question of the status of an intellectual in society becomes once again very important. The German ballad after World War II, in complete accordance with the new aesthetic thought that lost confidence in heavenly fair order, no longer tries to just tell the story, but to unveil the whole truth about the unimaginable experiences that cannot be absorbed by the old theodicy. Hence, there are no more ideals in the ballad, in the way as in the philosophy of the time, according to Horkheimer, there is no more God that could be absolutely good or almighty (Horkheimer, 1982). The critical philosophy of the Frankfurt School, that Theodor Adorno formulated in a comprehensive theory, strongly influenced the new understanding of art and what is artistic. Since the 1950s, Adorno claims there is no more space for metaphysics, asceticism or hedonism in the arts. He demands art to be an instrument of permanent social observation and the place where the truth about society and history can be unveiled (Adorno, 1977). His decisive demand influenced the postwar generation of authors who looked for their way between Brecht's left engagement and L'art pour l'art of Neoromanticism.

\section{Methods}

As an influential genre of German literature, artistic ballad revived as a literary but also as a musical form, in the second half of the $20^{\text {th }}$ century. ${ }^{2}$ Its popularity in the contemporary production undoubtedly has to do with its expressional possibilities. The important part of the research, resumed in the introduction of this paper, was therefore the theoretical consideration of the current understanding of the German artistic ballad and its expressional possibilities based on insight into the latest relevant literature.

Starting from this theoretical position, two ballads are selected from the second half of the $20^{\text {th }}$ century which focused on art and the artist, respectively the social role of the poet. Having in mind the thesis of Fritz Martini (1949) that the two German divergent literary scenes after World War II are parts of one common tradition of German literature, we selected one ballad from an author from the Federal Republic of Germany and another from a GDR author. Both of them, however, had a very critical relation to official politics.

The immanent text interpretation of Adorno's tongue (Adornos Zunge, 1965) from Günter Grass and Ballad to the Poet François Villon (Ballade auf den Dichter François Villon, 1968) from Wolf Biermann should show in which way the ballad, as a reflexive and auto reflexive genre, can at the same time be a good literary work and the voice of public, respectively, social criticism.

${ }^{2}$ As a musical genre, ballad dominates more than a half of the century the conformist scene around the world: pop ballad from Beatles and Bob Dylan, to Chris Christophers, as well as the musical-dancing narrative forms: rap and hip hop ballad (LL Cool J, Mac Dre, Jay Z, Kool Savas etc). 


\section{Analysis}

Günter Grass's cult novel Tin Drum (Blechtrommel, 1959) is a direct response to Adorno's demand that postwar art must scrutinize the role of an individual in the collective euphoria of National Socialism. Although Grass's literary work is featured by many postulates of Adorno's aesthetics, in the late '60s, he takes the side of Adorno's opponents who strongly criticized the discrepancy between the radical social criticism that Adorno's theory pled for and the fact that there was no realization of the criticism in practice at all. In his letters from the same period, Grass condemns the Frankfurt professor for not speaking up clearly enough for social democracy. In the short ballade Adorno's Tongue, he stands out against the sterility of Adorno's philosophy of language and "narcissistic infatuation of the 'golden-mouthed' in his own sweet words" (Frizen, 2007). Similar to the work of Bertolt Brecht, the intellectual in Grass's presentation is portrayed from the angle of his social responsibility - for doing and for not doing. Grass, however, shows no trace of belief in the didactic role of literature. Reducing the abstract ideas to their concrete, representational substitutes, the story of the ballad follows the questionable reception of Adorno's words. The tongue is used as a metaphor to refer to the emptiness of mechanical production of voices - talking without speaking and with no communicative value - and introduces the symbolism of a snake - sticking out its tongue - a serpent that tempts one to commit sin. The motive of the game in the first strophe falls short of expectations: instead of homo ludens, the narrator presents us with a spoiled intellectual that plays with the tongue. Playing with the tongue is a 'beautiful entertainment' for him. The attribute 'beautiful', stressed by repetition, suggests the concept of adoring beauty in arts, which turns Adorno's criticism of hedonism and L'art pour L'art against his own creator. Repeating the adverb 'alone' (alleine, 15-16), the narrator reproaches the philosopher of the radical social theory with the romantic individualism and egotism. ${ }^{3}$ That is additionally stressed by the mirror in Adorno's portrait. The mirror introduces the motive of Narcissus, who cannot act, captivated by his own reflection. The core of the ballad is actually an old conflict of action and contemplation that Grass presents through the means of grotesque. Grass's criticism does not save Adorno's recipients who are portrayed as butchers looking for a good piece of tongue. Their tendency to take home the beautiful object („trugen sie/ die schöne Zunge in ihr Haus“, 17-18) indicates their petty bourgeois orientation, even if 'house' is understood here as an individual cognitive capacity and not as the petty bourgeois interior. The principle of concretization of abstract ideas and realized metaphors are always present in Grass's expression. At the beginning, butchers are only a threat, but later on, they are coming into the house without knocking and with a knife, which refers to the crudeness of Adorno's recipients. They take for granted the nice sounding ideas, adopt them as their own, becoming ready to fight for them aggressively. When they butcher them, it is too late: „zu spät" stays separate from the last strophe, in the same way that 'beautiful ideas' stay separate, estranged from their creator.

Critical voices reverberate also in Biermann's Ballad to the Poet François Villon. Well-known as a critic of party dictatorship in the German Democratic Republic, Wolf Biermann rises here against the art that supports the communistic system. Biermann's ballads continue the tradition of Wedekind's cabaret songs that are sung by the author in front of an audience, thus their narrator is mostly identified with the poet himself. The first-person narrator of this ballad identifies himself as a poet of a rebel tradition, emphasizing that Villon is his brother. They share a room. He hides Villon in his closet "prompting him the verses of Brecht, when he forgets his own text" („Vergißt er seinen Text, soufflier/ Ich ihm aus Brechts Gedichten", 19-20). The clear conscious of a poet to be a part of a certain tradition is emphasized here by the tendentious use of the discourse of that tradition.

The ballad revives Villion's rebel spirit recalling the episodes from his life as well as the characters of his ballads like a "fat Margot" („die dicke Margot", 27), promoting in that way the concept of art as social criticism, rebellion and provocation. Art should be a bitter pill of truth that decisively opposes the stupidity of the world: "bitterly singing" ("mit seinen Bittersängen") is repeated three times, in the $32^{\text {nd }}, 33^{\text {rd }}$ and $37^{\text {th }}$ verses. The poet should be free - as a bird that sings freely in the woods. The problem of freedom of art is the central motive of the ballad:

\section{Dann sang er unverschämt und schön \\ Wie Vögel frei im Wald \\ Beim Lieben und beim Klauengehn (49-51)}

Beautiful is an aesthetic quality, but here it also relates to shamelessness, which additionally points out, not only freedom, but also the obligation of the poet to tell the truth without any limitations and with no shame. The motive of steal is part of the biographical motivation of the ballad concerning Villion's life, but can also refer to the relation of the postmodern literature to the previous tradition. The motives of love and wine traditionally find their place around the poet.

${ }^{3}$ All verses quoted with the verse number from Laufhütte, 1991a. 
However, sweet delirium of the romantic poetry is here replaced by heavy alcohol drunkenness, with spirit that "shoots in the brain“ („Der drückt inm aufs Gehirn“, 54) and love is reduced to the petty bourgeois merit of Maria's nightly visits. In order to stay alone with her, the narrator sends his brother Villon into the reality of divided Germany. The poet is a provocateur who dares to debunk the nonsense of the social life of his time. That is how one must understand the picture of Villon, who plays the barbed-wire-harp on the Berlin Wall while the border soldiers set the beat with their machine-gun fire.

\author{
Dann spielt er auf dem Stacheldraht \\ Aus Jux die große Harfe \\ Die Grenzer schießen Rhythmus zu \\ Verschieden nach Bedarfe (69-72)
}

However, nobody wants to hear the truth, not even as a joke, so the poet is being chased in this world and hereafter. The whole thing is discovered and the police come to visit the narrator, who hands over the closet, where his brother-poet hides, without any resistance. The art of provocation that demands truth as an aesthetic quality is a target of the doctrinal regime where brother betrays brother. Through the portrayal of a poet that stands for the concept of rebellion in art, Biermann snarled again at the regime of fear and unfreedom that ruled in East Germany. The answer of the firstperson narrator to the police, written in two strophes of eight verses, contains the sharp satirical portraits of a subservient citizen and the regime poet, both in fear and meek as a lamb, with no political influence, ignore the social questions.

Ein Lämmerschwänzchen bin ich

Ein stiller Bürger. Blumen nur

In Liedern sanft besing ich. (114-116)4

The motive of flowers recalls the picture from the first part of the ballad:

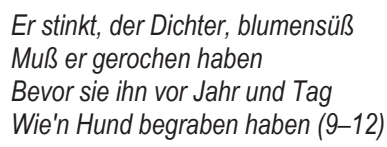

The rebellion of a poet like Villon, part of the literary tradition, where the narrator also includes himself, smells like rotting flesh and ends up buried like a dog. Honor and respect go to the one who sings about flowers - the top official of doctrinal GDR culture, Alfred Kurella, mentioned in false positive context. Inversions and verbal turns are an inevitable part of Biermann's satirical expression: from the harmful literature of Villon and Kafka, the frightened first-person narrator has to protect himself while reading the writings of Kurella. Moreover, such a good and doctrinal well-read citizen-poet turns into an informer, who betrays his brother. That is his best achievement. His disgust for that kind of artist, Biermann expresses through the metaphor of vomit („das Erbrochenes“, 119) - that is the only thing that the police found in the closet where the 'older brother', Villon, hid. In that way the ballad expresses the disgust for the concept of sentimental and futile art.

\title{
4. Results and Discussion
}

In Grass's ballad the literary topos of the bad influence of literature is once again a subject of discussion and the question that has been raised many times from Cervantes through Flaubert to Expressionism: is the responsibility for acting on the text or on the reader? Grass's criticism is a double-edged sword. The responsibility of the audience does not suspend the responsibility of the intellectual, who must be aware of the fact that a nice expression has a seductive strength. Art must be more than a beautiful word and the artist should be the live voice of the public, criticism and politics, which rises also against itself, if petrified in the ineffective patterns of the past.

Biermann portrays the poet as a rebel provocateur that dares to debunk the nonsense of the political and social life of his time. His first-person narrator expresses the disgust for the concept of sentimental, doctrinal and sterile art as well as for the society of unfreedom where such art blossoms. Both of them enchain man, reducing him to his instincts and fears, to the banality of an anonymous existence.

\footnotetext{
${ }^{4}$ The colloquial use of a noun Schwanz, $m$. (DIM Schwänzchen) as a word for male genitals, allows an additional satirical reading of Biermann's verses.
} 


\section{Conclusion}

The interpretation of the two selected ballads shows the way in which literature, as an aesthetic response to reality, can offer the relevant critical perception of society, considering the historical moment of origin of the text as well as the philosophical and existential views of the author.

Grass's reaction to Adorno's sterile aestheticism makes the role of the intellectual in modern society a subject of discussion, but at the same time, it also demonstrates how literature, in the form of a ballad, can react to the current topics without the risk of becoming political speech. It is the same with Biermann, who, criticizing the communist regime in East Germany, calls for the vivid and conscious, critical art that encourages new ideas and opposes fear and death in the way Villon's spirit did on the Berlin wall. The art of provocation demands truth as an aesthetic quality.

Both examples show the critical potential of the genre. The apparently naive narration of the ballad opens space for individual reflection, enabling the reader to come to his own conclusions, without docility and using his own cognitive and creative potential.

\section{References}

Adorno T. (1977). Kulturkritik und Gesellschaft. In Gesammelte Schriften, Band 10.1: Kulturkritik und Gesellschaft I, Prismen. Ohne Leitbild. Frankfurt am Main: Suhrkamp.

Bogosavljević, S. (2006). Laufhiteov model balade. Zlatna greda, 51-52, 50-55.

Frizen W. (2007). Günter Grass - Gedichte und Kurzprosa. Kommentar und Materialien. Göttingen: Steidl.

Horkheimer, M. (1982). Critical Theory, New York.

Knežević, J. (2013). Kako promeniti paradigmu? Ili i dalje o nemačkoj baladi. In Filološka istraživanja danas, Vol. 4 (pp. 35-50). Beograd: Filološki fakultet.

Laufhütte, H. (2009). Totgesagte leben länger. In Bogosavljević, S., Woesler, W. (Eds.), Die deutsche Ballade im 20. Jahrhundert (pp. 11-28). Bern.

Laufhütte, H. (1992). Ballade. In Killy, W., Meid, V. (Eds.), Literaturlexikon. Begriffe, Realien, Methoden. Vol. 13. (pp. 73-76). München: Bertelsmann Lexikon.

Laufhütte, H. (Ed.) (1991a). Deutsche Balladen, Stuttgart: Reclam.

Laufhütte, H. (1991b). Nachwort. In Laufhütte, H. (Ed.), Deutsche Balladen (pp. 592-632). Stuttgart: Reclam.

Martini, F. (1991). Deutsche Literaturgeschichte. Von den Anfängen bis zur Gegenwart. (19th ed.). Stuttgart: Alfred Kröner.

Müller-Seidel, W. (Ed.) (1980). Balladenforschung. Meisenheim: Anton Hain. 